Pamiętnik Literacki 2017, 3, s. 41-50
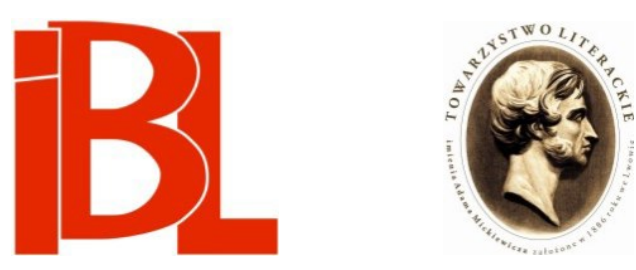

\title{
„Skarb duszny, nad złoto i kamienie drogie kosztowniejszy”. Z dziejów pewnej książki
}

\author{
Margarita A. Korzo
}


Pamiętnik Literacki CVIII, 2017, z. 3, PL ISSN 0031-0514

DOI: $10.18318 / \mathrm{pl} .2017 .3 .3$

MARGARITA A. KORZO Institut fiłosofii RAN, Moskwa

\section{„SKARB DUSZNY, NAD ZLOTO I KAMIENIE DROGIE KOSZTOWNIEJSZY” Z DZIEJÓW PEWNEJ KSIĄŻKI}

Katolickie piśmiennictwo dewocyjne drugiej połowy XVI stulecia, zwłaszcza dzieła w języku polskim, przeznaczone dla szerokich kręgów wiernych, było o wiele uboższe w porównaniu z produkcją książkową wyznawców różnych odłamów protestantyzmu. Duża jego część przygotowali albo wydali członkowie Towarzystwa Jezusowego ${ }^{1}$. Szczególną popularność zyskała Harfa duchowna jezuity Marcina Laterny (Kraków 1585), która miała zastapić średniowieczne książki do nabożeństwa prywatnego, ukazujące się jako Hortulus animae i Paradisus animae ${ }^{2} . Z$ drukami jezuickimi konkurowały modlitewniki i książeczki do medytacji autorstwa hiszpańskiego dominikanina Ludwika z Grenady, np. Przewodnik grzesznych ludzi (Kraków 1570) i Zwierzciadło człowieka krześcijańskiego (Poznań 1577)3.

Do rzadkich w XVI w. polskojęzycznych druków dewocyjnych należy ponadto anonimowy Skarb duszny, nad złoto i kamienie drogie kosztowniejszy, zamykajac $w$ sobie niemal wszystkie pobożne prawych chrześcijanów ćwiczenia. Bibliografia Karola Estreichera notuje dwie jego edycje: z 1582 r. (bez wskazania wydawcy i miejsca druku) ${ }^{4}$ oraz z 1594 r. (wytłoczoną w krakowskiej oficynie Andrzeja Piotrkowczyka) ${ }^{5}$. Chociaż w jednej i drugiej znajduje się adnotacja „teraz now o z łacińskiego języka na polski przełożony” (podkreśl. M. K.), jest mało prawdopodobne, aby istniały wydania wcześniejsze. Obie edycje są identyczne pod względem treści ${ }^{6}$ i szaty graficznej, co pozwala zaliczyć do produkcji Piotrkowczyka także tę z 1582 roku. Jedyna zasadnicza różnica to List papieski, w którym sposób czynienia juramentu około wyznania wiary powszechnej opisuje, czyli trydenckie wy-

$1 \quad$ Zob. J. Po plat e k, Działalność piśmiennicza i wydawnicza jezuitów w Polsce wieku XVI. Kraków 1954. Mpis (bez sygn.). Archiwum Prowincji Polski Południowej Towarzystwa Jezusowego w Krakowie. - M. Ko m or ow s ka, Ksiażki jezuickich pisarzy $w$ polskich oficynach drukarskich przełomu XVI i XVII wieku (na przykładzie drukarni Andrzeja Piotrkowczyka). W zb.: Retoryka Towarzystwa Jezusowego i jej konteksty. Red. Ł. Cybuls ki, K. Ko e hl e r. Warszawa 2014.

Zob. S. C i eśl la k, „Harfa duchowna”- modlitewnikowy bestseller jezuity Marcina Laterny (15521598). „Nasza Przeszłość” t. 93 (2000). - K. Krza k-W e is s, W ogrodzie duszy. Studia nad wyposażeniem graficznym polskich edycji modlitewnika „Hortulus animae”. Poznań 2014, s. 115-117. Zob. S. Ko p e r e k, Dzieje udostępniania wiernym „Mszału” (polskie przekłady mszalne dla użytku wiernych od XVI do XX wieku). W zb.: „Mszat” księgą życia chrześcijańskiego. Red. B. N a d ols ki. Poznań 1989, s. 248-249.

4 Bibl. Narodowa, XVI.0.6193; mf 1417.

5 Bibl. Jagiellońska, Cim.994; Bibl. Uniwersytetu Warszawskiego, 28.1.15.29 (Bibl. Narodowa, mf 33580).

$6 \quad$ Zob. K. Es tre i ch e r, Bibliografia polska. T. 28. Kraków 1930, s. 127. 
znanie wiary dołączone do druku z 1594 r. już po rejestrze, ale z paginacją ciagłą. Trudno ustalić, czy ten dodatek wchodził w skład edycji z 1582 r. - dostępny mi egzemplarz go nie zawiera ${ }^{7}$.

\section{Układ i treść Skarbu dusznego}

\section{Książeczka rozpoczyna się krótką Przedmową do czytelnika, która określa intencje tłumacza i charakteryzuje treść dzieła:}

Rozumiem temu, czytelniku miły, że jesli z umysłem miłością Bożą zapalonym a prawdziwym pragnieniem pożytku zbawienia dusze twojej do tych książeczek, teraz z łacińskiego języka na polski przełożonych (acz małych, ale wiele rzeczy zbawiennych w sobie zamykających), przystąpisz, obaczywszy w nich rozliczne pożytki dusze twej, słusznie je za skarb duszny mieć będziesz, a moję pracą w przekładaniu ich na polski język za wdzięczne przyjmiesz. Zalecenia też pragnąć nie będziesz, ponieważ się tym, co w sobie zamykają, samy dosyć zalecić mogą. Abowiem jesli chcesz być budownikiem duchownego Jeruzalem na tym świecie, to jest widzenia pokoju sumnienia twego przez oczyścienie jego, atoć te książeczki podają sposób budowania, ucząc cię, jako oczyściać sumnienie, jako się gotować do sakramentu pokuty świętej, którym pokoju sumnienia przez odpuszczenie grzechów dostawamy. K temu żeś tu miedzy wielą nieprzyjaciól, którzy ze wszech stron na cię biją, atoć wiele broni podają, to jest modlitwy, medytacje albo rozmyślania, ucząc cię rozmaitych sposobów, których używając, bronić się światu, ciału i dyjabłu, głównym nieprzyjaciołom twoim, możesz. Uczą cię też, jako uczciwości cerymonij kościelnych przestrzegać masz (na które nowowiernicy teraźniejszy, główni nieprzyjaciele Krysta Pana i Kościoła Jego, pobożności wszelkiej i uczciwości Bożej biją), krótko-ć ich tajemnice przed oczy kładąc. Dając też i plastry, które na rany dusze twej, to jest na pychę, łakomstwo, lenistwo etc., przykładać możesz. A żebyś na robocie tej nie ustał, dodają-ć siły i mocy, jakobyś godnym przyjęcim Ciała i Krwie Krysta Pana posilony mógł wszytki prace dla zbawienia twego potężnie, nie ustając, podejmować. Będziesz tedy mógł za pomocą Bożą z książek tych cnotami i dobrymi uczynkami jako kosztownym kamienim zbudować tu sobie na świecie takowe budowanie, które cię nie obwini jakoby próżnującego albo leniwego robotnika przed sądem tego Pana, który wszytkim płacić sprawiedliwie będzie, ale twoję pilność, wierność i stateczną robotę okaże. Przyjmiże tedy wdzięcznie, czytelniku łaskawy, tę maluczką pracą, którą tobie z miłości krześcijańskiej i z szczyrej żądze postępku twego duchownego ku twemu pożytkowi dusznemu podaję, skarbiąc sobie tym skarbem nie pieniądze, nie śrebro, nie majętność doczesną, ale nieprzemienne dobra i wiekuiste, których żadna przygoda odjać, żadna rozkosz ani żadna zacność przewyższyć nie może. Amen ${ }^{8}$.

Skarb duszny podzielony jest na trzy części. Początkowa, największa pod względem objętości, składa się z czterech bloków tematycznych. W pierwszym $z$ nich podano wskazówki praktyczne związane $z$,gotowaniem się na spowiedź” i przedstawiono „wywody do zalecania częstej spowiedzi”, szczegółowy rachunek sumienia „ze strony dziesięciorga przykazania Bożego” oraz rozważania o rodzajach grzechów i „córkach ich”, a także o „okolicznościach grzechowych”. Dalej omówiono czynności dotyczące sakramentu Eucharystii (,jak się człowiek przygotować ma do przyjęcia [...] sakramentu”, „co mamy zachować w przystępowaniu i po przystępowaniu”,

$7 \quad$ Są też drobne różnice w paginacji. W obu edycjach k. 37 występuje dwa razy, ale błędna kolejność k. 77, 75, 79 - tylko w edycji z 1594 roku. Poza tym skrót „de summa Trini.” (1582, k. 205v) został mylnie podany w drugim wydaniu jako „de summa Tridi.” (k. 205v).

8 Przedmowę cytuję $\mathrm{z}$ wydania $\mathrm{z}$ r. 1582 (Bibl. Narodowa, XVI.0.6193, k. 2r-4v), pozostałe zaś cytaty pochodzą z edycji z r. 1594 (Rosyjska Bibl. Państwowa w Moskwie. Muzeum Książki, 10931; egzemplarz nie ma karty tytułowej ani przedmowy, a dane wydawnicze umieszczone są na ostatniej karcie). 
„wywody [...] dla częstszego przystępowania do [...] sakramentu” i „dwa wywody przeciw częstemu przystępowaniu $z$ ich zbijanim”). W kolejnym bloku, poświęconym mszy, zaprezentowano wykład teologiczny i ascetyczny obrzędu, ponadto zaś objaśniono symbolikę szat liturgicznych ${ }^{9}$. Później następują rozległe rozważania o modlitwie, w tym o „modlitwie wnętrznej, albo rozmyślaniu”, o „błękaniu myśli na modlitwie” i lekarstwach przeciwko roztargnieniu, o „sposobieniu ciała czasu modlenia". Ów blok zawiera również wykład pacierza i Pozdrowienia Anielskiego, przytacza modlitwy „zaranne i wieczorne”, „rozmyślania powszednie wedle porządku dni tegodniowych" oraz dwie modlitwy św. Tomasza z Akwinu.

Część druga zaczyna się od refleksji o znamionach i przymiotach Kościoła prawdziwego („Śrzodki ku zachowaniu prawdziwej a powszechnej wiary”). Jest to jedyny w całym dziele akapit o wyraźnym charakterze polemicznym. Następnie podano sposoby „ku wykorzenieniu złego zwyczaju przysięgania” i uwagi o tym, „,o nas ma wzbudzać ku czczeniu rodziców i starszych”, przytoczono „lekarstwa” przeciwko grzechom głównym, a wreszcie udzielono rad do nabycia pokory, cierpliwości i ku otrzymaniu „prawdziwego wesela serdecznego”.

Część trzecia i zarazem ostatnia obejmuje refleksje o znaku Krzyża Świętego. Opisano tam liturgię sakramentów, obszernie skomentowano liturgię roku kościelnego, omówiono użycie wody święconej, rózg palmowych, świec i gromnic, a także świętość Baranka Bożego.

Warto dostrzec praktyczny charakter Skarbu dusznego. Nie zawiera on rozważań teoretycznych ani zawiłej argumentacji teologicznej, podaje za to wiele pomocnych wskazówek, co wyróżnia go na tle niezbyt jeszcze licznych polskojęzycznych druków dewocyjnych $z$ końca XVI wieku. Nie można jednoznacznie określić gatunku omawianej książki. $Z$ pewnością nie należy ona do katechizmów (pomimo że uwzględnia wykład wybranych prawd wiary) ani do dzieł sensu stricto ascetycznych, ani też do modlitewników (chociaż badacze dorobku wydawniczego Andrzeja Piotrkowczyka zaliczają ją właśnie do owego gatunku, podkreślając, że podobnie jak „największa ilość druków tego typu, związana była z kultem maryjnym" ${ }^{10}$ ).

\section{Łacińskie źródło Skarbu dusznego i hipotezy autorstwa}

Zarówno adnotacja na karcie tytułowej, jak i przedmowa świadczą o tym, że Skarb duszny opiera się na źródle łacińskim. Analogiczne wzmianki, występujące często

9 Omówienie części i obrzędów mszy niezbyt często spotyka się w drukach adresowanych do wiernych. Do wyjątków należą Harfa duchowna M. Laterny, dzieła Ludwika z Grenady (np. Wizerunk żywota chrześcijańskiego pobożnego. Poznań 1584 〈Bibl. Narodowa, XVI.0.927〉) i niektóre XVI-wieczne modlitewniki niemieckie (np. Außerlesen gulden Schatzbüchlein Christlichen andechtigen Katholischen Gebett. Köln 1571, k. 40 n.), a wcześniej Hortulus animae (np. [Nürnberg] 1521; Antverpiae 1564) i słynny Speygel der leyen (Lübeck 1496, k. 7r-21v). W okresie potrydenckim zagadnienia obrzędowości przedstawiano w drukach dewocyjnych po to, by podtrzymać tożsamość konfesyjną i zdystansować się od innowierczych nowinek religijnych. Zob. J. M. Fry mire, Demonstrationes catholicae: Defining Communities through Counter-Reformation Rituals. W zb.: Defining Community in Early Modern Europe. Ed. M. J. Halv o r s o n, K. E. S p i e r lin g. Aldershot 2008.

10 Drukarze dawnej Polski od XV do XVIII wieku. T. 1: Małopolska. Cz. 1: Wiek XV-XVI. Red. A. Kawecka-Gryczowa. Wrocław 1983, s. 154. 
w piśmiennictwie staropolskim, mogły być prawdziwe (ponieważ takie wzorce zawsze istniały), a zarazem nieprawdziwe (gdyż służyły legitymacji i prestiżowi książeczki) ${ }^{11}$. Przemyślany układ dzieła pozwala sądzić, że - o ile mamy do czynienia z tłumaczeniem - jest to raczej przekład bądź parafraza jednego dzieła niż kompilacja różnych prac. Wbrew podobieństwu nazwy nic nie łączy go z licznymi utworami łacińskimi, które drukowano w XVI w. pod tytułem Thesaurus spiritualis ${ }^{12}$. Łaciński oryginał Skarbu dusznego powstał po zakończeniu prac Soboru Trydenckiego w r. 1563 (w tekście spotykamy sporadyczne odwołania do dekretów soborowych - zob. np. k. 234v) i zapewne przed r. 1582, czyli przed wydaniem przekładu na język polski ${ }^{13}$.

Próba ustalenia daty powstania źródła łacińskiego na podstawie występujących w Skarbie dusznym odesłań do innych tekstów XVI-wiecznych nie przyniosła pozytywnych rezultatów. Dotyczy to np. wzmianki o siódmym tomie dzieł Marcina Lutra (k. 149r) i o pracy De frequenti communione (k. 66r). Opera omnia niemieckiego reformatora ukazały się drukiem jeszcze przed zakończeniem Soboru Trydenckiego ${ }^{14}$. W drugim wypadku chodzi zaś prawdopodobnie o dzieło Hieronima Cacciaguerry (1494/95-1566), które powstało pierwotnie w języku włoskim ${ }^{15}$. Najwcześniejsze znane tłumaczenie łacińskie, autorstwa Michaela von Isselt (1530/40-1597), datuje się na 1586 rok. Odtąd łacińską wersję tejże pracy drukowano zazwyczaj razem $z$ dziełem Ludwika $z$ Grenady o tym samym tytule. Ale nawet w wydaniach Cacciaguerry w językach narodowych sprzed 1586 r. jego dzieło określane jest po łacinie właśnie jako De frequenti communione ${ }^{16}$.

Więcej możliwości uściślenia daty powstania łacińskiego oryginału Skarbu dusznego daja fragmenty dotyczące początków reformacji: w tekście dwukrotnie spotykamy wzmiankę, iż jeszcze przed 60 laty nie było „sekciarzy”. Pierwsza z nich

11 Zwróciła na to moją uwage prof. Ali na N owi c ka - J e żowa.

12 Zob. np. Thesaurus spiritualis cum psalterio. Lugdunum 1512. - Ph. Ke ge 1, Thesaurus spiritualis precationum piarum. Magdeburgum 1596. Należą one do grupy modlitewników wzorowanych na Hortulus animae. W Polsce tradycję tę kontynuowała Harfa duchowna.

13 Za błędne trzeba uznać spotykane w literaturze przypuszczenie, iż Skarb duszny ukazał się już w 1543 roku. Zob. Ko p e re k, op. cit., s. 247.

14 Zob. S. Michel, Die Kanonisierung der Werke Martin Luthers im 16. Jahrhunderts. Tübingen 2016.

15 Zob. M. Regazzoni, L'epoca delle riforme e della Controriforma. W zb.: Storia della spiritualità italiana. A cura di P. Zovat to. Roma 2002, s. 352.

16 Zob. np. tłumaczenie niemieckie z r. 1571: De frequenti Communione. Aussfürlicher Bericht und Erklärung von der Communion [...] durch D. Philippum Dobereiner [...] auss dem Hieronymo Cacciaguerra verdolmetscht, Dilingen. Warto odnotować, że piśmiennictwo katolickie tej epoki obfitowało w dzieła uzasadniające praktykę częstej Komunii; większość z nich wyszła spod pióra jezuitów. Jako przykład przytoczmy Della frequenza della communione jezuity włoskiego Fulvia An d r o zi a (ok. 1579), a także De frequenti usu Sanctissimi Eucharistiae Sacramenti jezuity hiszpańskiego Cristóbala M a d ri d a (1555), które drukowano często jako dodatek do słynnego również w Polsce manuału jego współbrata Juana Alfonsa d e Pola n c o Breve Directorium ad confessarii ac confitentis (1560; w Polsce ukazało się w 1566 r. w Łowiczu u S. Murmeliusa 〈Bibl. Narodowa, XVI.0.407)). Jezuici polscy poruszali to zagadnienie także w związku z polemiką antyprotestancką, zaprzeczając zdaniu, iż „[my], katolicy, lud wierny Chrystusów, od używania tego przenaświętszego Sakramentu odganiamy, a ledwie ich raz w rok albo dwa przypuszczając do tej niebieskiej potrawy" (P. Sk a r ga, Siedm filarów, na których stoi katolicka nauka o przenaświętszym Sakramencie ottarza. [Wilno] 1582, k. 227r). 
została umieszczona w kontekście rozważań o tym, że istnieje tylko jeden prawdziwy Kościół i że jest to Kościół rzymski:

gdyby był kto przed 60 lat, kiedy jeszcze żaden $z$ tego nowego zgromadzenia nie narodził się był, spytał kogo po wszystkim świecie, a osobliwie w tych stronach, kędy teraz nowe sekty kwitną, o Kościele, albo o tym, albo o owym, żaden by był inszego nad rzymski nie ukazał. [k. 152v]

W kolejnej wzmiance ze Skarbu dusznego znajdujemy datę wystapienia Lutra oraz informację, że od tego czasu minęło zaledwie 60 lat:

co ci nowi sektarze, naśladownicy Lutrowi, Bucerowi, Kalwinowi etc., uczą, to idzie, że przed 60 lat żadnej prawdziwej wiary ani Kościoła nie było, gdyż wiemy, że Marcin Luter dopiero roku 1517 swoje błędy wymyślił i na świat przyniósł. [k. 153r-153v]

Na podstawie przytoczonych wypowiedzi można przypuszczać, iż oryginał łaciński ukazał się między 1577 (czyli $1517+60$ ) a 1582 r. (data wydania polskiego przekładu ${ }^{17}$.

Uściślenie ram chronologicznych publikacji pozwoliło na ustalenie oryginału łacińskiego. Był to Thesaurus piarum et christianarum Institutionum in usum catholicae iuventutis. Praesertim vero Sodalitatis Deiparae Virginis, który ukazał się drukiem co najmniej trzykrotnie (Ingolstadt $1578^{18}$, przedmowa datowana na 24 IX 1576; Dillingen $1583^{19}, 1591^{20}$ ) jako praca autorska niejakiego Johannesa Perelliusa. Wspomniany fragment o początkach reformacji znajduje się w wydaniu z 1578 r. na s. 142-143, a w edycji z 1591 r. - na s. 153.

Kolejną zagadkę stanowił autor Thesaurus piarum- Johannes Perellius. Sądząc po treści dzieła, powstało ono najprawdopodobniej w kręgu jezuitów albo w najbliższym im otoczeniu, ponieważ książka adresowana jest do członków Sodalicji Mariańskich (Praesertim vero Sodalitatis Deiparae Virginis), które zakładano prawie przy każdym kolegium Towarzystwa Jezusowego. I rzeczywiście, pod pseudonimem Johannes Perellius ukrywał się Franciszek (Franz, François) Coster, żyjący w latach 1531-1619 jezuita belgijski, związany z kolegium TJ w Kolonii ${ }^{21}$. Należał on do pierwszej generacji jezuitów, odbył studia w Rzymie i Lowanium, po 1556 r. wykładał w Collegium Tricoronatum, pełnił również obowiązki prowincjała oraz rektora w kolegiach w Brugii i Douai. Będąc autorem licznych prac pouczających i ascetycznych, a także szerzących duchowość maryjną, Coster należał do fundatorów powstałej w Kolonii na przełomie 1575-1576 r. Sodalicji Mariańskiej. Prawie wszystkie jego dzieła drukowane stanowiły odzwierciedlenie aktywnej pracy duszpasterskiej. I właśnie na potrzeby Sodalicji, jak również dla katechizacji wiernych

Zauważmy na marginesie, że w obu polskich edycjach liczba 60 lat od początku reformacji nie została zaktualizowana, chociaż już nie odpowiadała rzeczywistości. W innym zaś miejscu, gdzie chodzi o rok bieżący, oba druki podają właściwe daty, czyli 1582 i 1594 (w jednym i drugim wypadku - zob. k. 153r).

Zob. Verzeichnis der im deutschen Sprachbereich erschienenen Drucke des 16. Jahrhunderts. Na stronie: https://www.bsb-muenchen.de, poz. P 1580.

19 Zob. ibidem, poz. ZV 25998.

$20 \quad$ Zob. ibidem, poz. P 1582.

21 Zob. E. W ell e r, Lexicon Pseudonymorum. Wörterbuch der Pseudonymen aller Zeit und Völker oder Verzeichnis jener Autorem, die sich falscher Namen bedienten. Hildesheim - New York 1977, s. 421. 
ułożył on swój Thesaurus piarum ${ }^{22}$. Jezuita ten jest znany ponadto jako utalentowany polemista i autor podręcznika teologii polemicznej, czyli tzw. kontrowersji: Enchiridion controversiarum praecipuarum nostri temporis (Coloniae 1585) ${ }^{23}$.

Dzieło Costera przeszło pewna ewolucję ${ }^{24}$. Wydanie pierwotnie zostało wydrukowane w Kolonii w 1576 r. jako Bulla super forma iuramenti professionis fidei; cum piis christianis Institutionibus, in usum Sodalitatis B. Mariae Virginis. Do końca XVI w. ukazały się jeszcze co najmniej dwie edycje pod tym samym tytułem (Colonia $1577^{25}$; Ingolstadt $1579^{26}$ ). Wszystkie trzy sa anonimowe, zawierają wstęp datowany 24 IX 1576, aprobacje z lipca $1575^{27}$, Bulla S. D. N. D. Pii Divina providentia papae IIII. super forma iuramenti professionis fidei (czyli wyznanie, które nadało nazwę całości) oraz teksty dodatkowe, związane z założeniem Sodalicji i wykorzystywane przez jej członków do nabożeństwa codziennego: De Agno Dei, Carmen Andreae Frusii, SI, Orationes seu meditationes variae de Passione Domini ex officio Beatae Mariae Virginis, Regulae seu ordinationes Confraternitatis Beatissimae Virginis Mariae, institutae inter studiosos Collegii SI Coloniensis, zatwierdzenie Sodalicji przez papieża Grzegorza XIII od 10 IX 1577, litanie i hymny do Bogarodzicy.

Dzieło to drukowano po 1578 r. również pod nazwą Thesaurus piarum i pod pseudonimem Johannes Perellius. Zmniejszono liczbę dodatków (De Agno Dei Carmen, Regulae et Ordinationes 〈które adresowano już nie tylko do Sodalicji kolońskiej, ale także do Collegiorum SI in Germania〉, aprobacja Grzegorza XIII i litania do Matki Bożej), a trydenckie wyznanie wiary tym razem zamykało całość. Właśnie na podstawie Thesaurus piarum powstawały pierwsze tłumaczenia na języki narodowe ${ }^{28}$.

Równocześnie wielokrotnie tłoczono dzieło Costera - nie wskazując ani jego autorstwa, ani też autorstwa „Johannesa Perelliusa” - pod tytułem Piarum et christianarum Institutionum libri tres (Coloniae 1581$)^{29}$. Jedna $\mathrm{z}$ edycji ukazała się w 1583 r. w Poznaniu w drukarni Jana Wolraba ${ }^{30}$. Za podstawe dla tego dzieła

Zob. E. M e u th e n, Kölner Universitätsgeschichte. T. 1. Köln-Wien 1988, s. 354-355. - U. B r z os a, Die Geschichte der katholischen Kirche in Düsseldorf. Von den Anfängen bis zur Säkularisation. Köln 2001, s. 448. - S. M o s t a c c i o, Early Modern Jesuits between Obedience and Conscience during the Generalate of Claudio Acquaviva (1581-1615). Farnham 2014, s. 46-47.

Zob. A. de Backer, C. So mmervogel, Bibliothèque de la Compagnie de Jésus. T. 2. Bruxelles-Paris 1811, kol. 1510-1534.

W tym artykule nie zamierzam rozstrzygnąc sprawy źródeł pracy Costera. Funkcjonowało wówczas wiele podobnych dzieł, które mogły zainspirować belgijskiego jezuitę, np. Trattato della Confessione et Communione Ludwika $z$ Grenady (wersja pierwotna sprzed 1574 r.).

Zob. Verzeichnis [...], poz. ZV 16645.

Zob. ibidem, poz. P 1583.

W literaturze spotykamy opinię, iż Coster ułożył dzieło $\mathrm{z}$ własnych pouczeń wygłaszanych do członków Sodalicji (zob. J. M ill e r, Die Marianischen Kongregationen im 16. und 17. Jahrhundert: ihr Wesen und ihr marianischer Charakter. „Zeitschrift für katholische Theologie” 1934, nr 1, s. 101). Fakt, że dzieło zostało zaaprobowane już w r. 1575, czyli przed oficjalnym powstaniem Sodalicji w Kolonii w r. 1576, podważa ową opinię.

28 Najwcześniej - wersja niemiecka: Schatzbüchlein oder Wegweiser der gnadenreichen Sodalitet der H. Mariae (Ingolstadt 1579, 1588; Münster 1614, 1623).

29 Kolejne wydania: Duaci 1582; Viennae 1583; Dilingae 1583; Duaci 1585; Leodii 1586; Mediolani 1586.

30 Institutionum. Piarum et Christ. Institutionum Libri tres, in usum Sodalitatis B. Mariae Virginis primum 
służyło raczej pierwotne wydanie Bulla super forma iuramenti professionis fidei (nie zaś Thesaurus piarum), bo wyznanie trydenckie znajduje się na początku, na odwrocie karty tytułowej zamieszczono wiersz z Bulla, zatytułowany Catholico pioque lectori, a Regulae seu Ordinationes dotyczą tylko (jak w Bulla) Confraternitatis [...] Collegii SI Coloniensis (podkreśl. M. K.). W dodatkach na końcu pojawił się całkiem nowy tekst: Jubilus Sancti Bernardi Abbati.

Jakkolwiek okoliczności powstania edycji poznańskiej nie zostały do końca wyjaśnione, wiadomo, że Wolrab dosyć intensywnie obsługiwał kolegium jezuickie w Poznaniu; jezuici również chętnie korzystali z jego drukarni i finansowali potrzebne im wydawnictwa ${ }^{31}$. Dzieło Costera było zapewne przeznaczone dla miejscowej Sodalicji, założonej jeszcze w r. 1574, do której 12 lat później dołączono tzw. Sodalicje „starszą"32.

Z czasem praca Costera została też rozszerzona ( $\mathrm{z}$ trzech części jak w Bulla, Thesaurus piarum i Piarum et christianarum Institutionum do pięciu). I właśnie w takiej 5-częściowej postaci drukowano ją zawsze ze wskazaniem prawdziwego imienia twórcy - pod tytułem Libellus Sodalitatis, hoc est: christianarum Institutionum libri quinque. Auctore Francisco Costero (Antverpiae 1586) ${ }^{33}$. W przedmowie autor opowiada o historii powstania dzieła, o tym, że pierwsza edycja ukazała się jako Bulla, a także opisuje wprowadzone przez siebie uzupełnienia ${ }^{34}$. Nową część, De quattuor Novissimis vitae humanae (dodaną między częściami drugą i trzecią), drukowano potem również osobno; ostatnia - piąta - część zawiera wykłady modlitw Ojcze nasz i Zdrowaś Maryjo (wcześniej znajdujące się w części pierwszej) oraz Apostolskiego wyznania wiary ${ }^{35}$.

Porównanie wymienionych edycji pracy Costera świadczy o tym, że pod względem treści pierwotny tekst ulegał bardzo niewielkim zmianom. Poprawiano zazwyczaj (chociaż nie we wszystkich wydaniach) fragment o początkach reformacji, na którego podstawie udało się ustalić datę powstania łacińskiego oryginału Skarbu dusznego.

conscripti, nunc vero omnium Christianorum Pietati ac Deuotioni destinati vna cum S. D. N. D. Gregorij XIII. Ponti. Max. dictae Sodalitatis aprobatione gratijs et indulgentijs eidem Sodalitati concessis (Bibl. Ossolineum, XVI.0.245).

31 Zob. Drukarze dawnej Polski od XV do XVIII wieku, t. 3, cz. 1: Wielkopolska (oprac. A. Ka w e c k a - Gryczowa, K. Korotajowa, J. Sójka. 1977), s. 273, 275.

Zob. Kronika jezuitów poznańskich (młodsza). T. 1: 1570-1653. Oprac. L. Grze bi eń, J. Wi esiołow ski. Poznań 2004, s. 28. - K. Bi elawny, Kongregacje Mariańskie $w$ Polsce $w$ latach 1571-1914. „Ateneum Kapłańskie” 2009, z. 3, s. 331.

33 Do końca XVI w. ukazało się jeszcze co najmniej 7 wydań: Coloniae 1586; Antverpiae 1587, 1588; Ingolstadii 1588 (w wersji poprawionej); Lugduni 1594; Ingolstadii 1597. Coster ułożył dzieło o podobnej nazwie (Manuale Sodalitatis, sive christianarum Institutionum libellus), ale o całkiem odmiennej treści.

Zob. Libellus Sodalitatis. Coloniae 1603, k. 6r-6v (Herzog August Bibliothek, Wolfenbüttel, Xb 5783).

Zauważmy na marginesie, że w poszczególnych edycjach Libellus Sodalitatis (Coloniae 1603, 1610) na karcie tytułowej zamieszczona jest rycina Matki Bożej z Dzieciątkiem na obłokach. Podobną rycinę spotykamy już w poznańskim wydaniu Wolraba. Wersja Wolraba to rycina o rozwiniętych cechach renesansowych (zob. Drukarze dawnej Polski od XV do XVIII wieku, t. 3, cz. 1, s. 278); w wydaniach zaś kolońskich rycina jest raczej w duchu pobożności potrydenckiej. 


\section{Dzieła Costera na gruncie polskim}

Jak już wspomniano, Skarb duszny został ułożony na podstawie Thesaurus piarum, choć bez wskazania Johannesa Perelliusa jako autora. Powstaje wrażenie, że krakowski wydawca nie wiedział o poznańskiej edycji dzieła Costera. Rezygnacja niemal ze wszystkich dodatków oprócz Credo trydenckiego może sugerować, że Piotrkowczyk pragnął nadać swojej edycji charakter bardziej uniwersalny w porównaniu $z$ manuałem dla członków Sodalicji Mariańskich i adresował Skarb duszny do szerszych kręgów wiernych. Przypuszczalnie właśnie dlatego tłumaczenie ukazało się bez imienia autora; możliwe, że nie chciał on też odstraszyć potencjalnych czytelników, $\mathrm{z}$ różnych powodów nieprzychylnie nastawionych do dorobku piśmienniczego jezuitów zagranicznych. Jednocześnie na początku XVII w. prace Costera ukazywały się w Polsce pod jego własnym imieniem: w samym Krakowie pięciokrotnie publikowano jego dzieło De quattuor novissimis vitae humanae, które stanowiło trzeci rozdział Libellus Sodalitatis (w wersji łacińskiej w latach 1603 i 1605, po niemiecku w r. 1606, dwukrotnie po polsku w przekładzie Piotra Skargi w 1606 r.) ${ }^{36}$.

Trudno rozstrzygnać pytanie o potencjalnych tłumaczy pracy Costera na język polski. Była to zapewne osoba wywodzaca się z Towarzystwa Jezusowego lub związana z kręgiem zakonnym - a może nawet sam Piotrkowczyk, który aktywnie współpracował $z$ jezuitami. W produkcji wydawniczej jego oficyny ponad połowę pozycji stanowiły druki religijne, w tym różnorodna literatura dewocyjna; właśnie u niego ukazały się pierwsza edycja modlitewnika Laterny (1585), a także Officium albo Godziny błogosławionej Panny Marii Jakuba Wujka (1598) ${ }^{37}$.

\section{Skarb duszny a piśmiennictwo prawosławne Rzeczypospolitej}

Skarb duszny nie tylko funkcjonował w polskim środowisku katolickim ${ }^{38}$, ale również trafił do rąk czytelnika prawosławnego. Fragment części pierwszej, zatytułowany Wywody przez podobieństwa króciuchne i każdemu człowiekowi ku pojęciu łacne do zalecenia częstej spowiedzi, został przetłumaczony na tzw. prostą mowę i wydany jako pouczenie o spowiedzi w szeregu półustawów prawosławnych ${ }^{39}$ tłoczonych w brackich drukarniach Wilna i Jewia w drugiej połowie lat trzydziestych

Zob. de Backer, Sommervoge1, op. cit., kol. 1518-1520. - Estreicher, op. cit., t. 14 (1896), s. 430-431. - J. Ko w z a n, Franciszek Coster i Piotr Skarga. Dwa utwory „de quattuor hominis novissima” - próba analizy porównawczej. „Acta Universitatis Wratislaviensis. Prace Literackie” 41 (2002). - M. Ko morow ska, „Nowoczesność” staropolskich przekładów literatury religijnej (na przykładzie tłumaczeń Piotra Skargi). W zb.: Tłumacz: sługa, pośrednik, twórca? Red. M. Guławska-Gawkows ka, K. Hejwowski, A. Szczę s ny. Warszawa 2012, s. 382-383. Zob. Drukarze dawnej Polski od XV do XVIII wieku, t. 1, cz. 1, s. 150, 152. - M. K o m o r o w s k a, Prolegomena do edycji dzieł Piotra Skargi. Kraków 2012, s. 154-155.

38 Dla przykładu: benedyktynki zamawiały ten druk około 1590 r. dla biblioteki w planowanej filii klasztoru w Nieświeżu. Zob. K. Gó r s k i, Matka Mortęska. Kraków 1971, s. 43.

39 Półustaw to rodzaj prawosławnej księgi religijnej o treści mieszanej, biblijno-liturgicznej. Zob. O. N a r b u t t, Historia i typologia ksiag liturgicznych bizantyńsko-słowiańskich. Zagadnienie identyfikacji według kryterium treściowego. Warszawa 1970. 
i na początku lat czterdziestych XVII stulecia. Przekład wiernie oddaje tekst polski, pominięte zostały tylko wątki, które mogły zdradzić katolicką proweniencję tekstu, np. porównanie grzechu $z$ długiem pieniężnym, którego zwrotowi towarzyszy otrzymanie poświadczenia. Chociaż był to wątek biblijny, prawosławni mogli kojarzyć owa praktykę z odpustami albo miłościwymi latami, kiedy rozgrzeszeniu towarzyszyło otrzymanie indulgencji w postaci pisemnego zaświadczenia.

W okresie późniejszym pouczenie znika z kart półustawów. Brak zachowanych opisów biblioteki brackiej, również opisów jakichkolwiek prywatnych zbiorów członków bractwa wileńskiego uniemożliwia odpowiedź na pytanie, jak XVI-wieczne wydanie krakowskie trafiło do wyznawców prawosławia Wielkiego Księstwa Litewskiego. Nie da się też na razie ustalić, kto podjął trud tłumaczenia Skarbu dusznego na "prostą mowę" 40 .

Znana jest ponadto druga próba przekładu tego dzieła na język literacki używany przez prawosławnych metropolii kijowskiej: w 1671 r. obszerne fragmenty Skarbu dusznego ukazały się w drukarni Ławry Kijowsko-Peczerskiej jako osobny druk $z$ tytułem Nauka o tajnie s. pokajanija (Nauka o sakramencie pokuty świętej). Pracę nad dziełem pobłogosławił archimandryta Ławry Innocenty Gizel (ok. 1600 1683). Przedmowa do Nauki nie wspomina o jej źródłach polskich bądź łacińskich. Ze Skarbu dusznego zostały zapożyczone tylko fragmenty dotyczące sakramentu spowiedzi, rachunku sumienia, analizy różnego rodzaju grzechów i „lekarstw” na nie. Wywody przez podobieństwa króciuchne, opublikowane już wcześniej w składzie półustawów wileńskich, pełnią w druku kijowskim funkcję zakończenia. Związany $z$ Ławrą tłumacz prawdopodobnie nie znał przekładu wileńskiego, korzystał bowiem z wersji polskiej i tłumaczył Wywody przez podobieństwa króciuchne w całości. W pozostałych fragmentach kijowskiej wersji Skarbu dusznego tekst został poddany redakcji, polegającej na rozszerzeniu i uzupełnieniu treści: tłumacz nie wymyślił nowych wątków, lecz dodał pewne szczegóły odzwierciedlające praktykę codziennego życia prawosławnych (przebieg postów, kontakty z otoczeniem różnowierczym, itd.).

Podobnie jak w przypadku półustawów wileńskich, nie sposób ustalić, dlaczego wydawcy Ławry sięgnęli właśnie po druk krakowski ani kto był jego tłumaczem. To ostatni przykład wydania Skarbu dusznego przełożonego na „prosta mowę” w XVII stuleciu, lecz nie ostatni epizod jego udostępniania w innych kręgach konfesyjnych: w 1686 r. na ziemiach współczesnej Ukrainy Zachodniej została przez unitów wykonana kopia Nauki z $1671 \mathrm{r}^{41}$ i od tego czasu to dzieło rozpowszechniano również w wersji rękopiśmiennej ${ }^{42}$.

40 Więcej na temat tego tłumaczenia zob. M. A. Ko r z o, Istorija odnogo tieksta. Pouczenije ob ispowiedi $w$ sostawie wilenskich „Potuustawow” XVII w. „Studi Slavistici” t. 13 (2016).

41 Bibl. im. W. Stefanyka Ukraińskiej Akademii Nauk we Lwowie, rkps MB-532, k. 1-106.

42 Jak zgodnie twierdzą badacze, nie tylko w stuleciu XVII, ale również w czasach późniejszych na terenach byłej metropolii kijowskiej „rękopisy wciąż stanowiły przeważającą część zbiorów cerkiewnych i klasztornych, a także prywatnych” (M. T o p o ls k a, Biblioteki $w$ Wielkim Księstwie Litewskim w XVI i pierwszej połowie XVII wieku. „Pamiętnik Biblioteki Kórnickiej” t. 20 〈1983〉, s. 144). 
Abstract

MARGARITA A. KORZO, Institute of Philosophy, Russian Academy of Sciences, Moscow

"SKARB DUSZNY, NAD ZKOTO I KAMIENIE DROGIE KOSZTOWNIEJSZY" ("A SOUL TREASURE, COSTLIER THAN GOLD AND PRECIOUS STONES") FROM A STORY

OF A BOOK

The article is an attempt at reconstructing the Latin source of the Polish devotional print Skarb duszny, nad złoto i kamienie drogie kosztowniejszy (A Soul Treasure, Costlier than Gold and Precious Stones) and the history of its translations done by the Orthodox Church followers in the Polish-Lithuanian Commonwelth. It was a translation of a work by a Jesuit Francis Coster composed about 1576-1577 to serve the Sodality of Our Lady, College Society of Jesus in Cologne, and printed at the turn of $16^{\text {th }}$ and $17^{\text {th }} \mathrm{c}$. under various titles (Bulla super forma iuramenti professionis fidei, Thesaurus piarum, Piarum et christianarum Institutionum libri tres, Libellus Sodalitatis), indicating Coster as its author or anonymously. A Soul Treasure [...], launched in Cracow in Andrzej Piotrkowczyk's publishing house (1582, 1594), was twice translated into so-called simple language and printed in Vilnius Orthodox Brotherhood as a kind of biblical-liturgical Orthodox book, either in the second half of the 1630s or at the beginning of 1640s (a fragment urging to frequent confession), and as a separate print Nauka o tayne suatovo pokayania (A Study of Mysterious Holy Confession, Kiev 1671). At the turn of $17^{\text {th }}$ and $18^{\text {th }} \mathrm{c}$. translation of A Soul Treasure [...] into simple language widespread in Ukraine also in handwritten transcripts. 